\title{
Casting of Al-Si alloys in the full-mould technology. Process conditions
}

\author{
Odlewania stopów Al-Si w technologii pełnej formy. \\ Uwarunkowania procesu
}

\begin{abstract}
A review of various technologies using expendable casting patterns made of expanded polystyrene is given in the paper. The results of our own investigations on implementing this technology at the pilot-plant scale - for the art castings series - were presented. The results of tests of materials and moulds applied in the full-mould technology were shown. Gas evolution tendencies of expanded polystyrenes and protective coatings were estimated. Gas evolutions were described as functions of the polystyrene heating temperature. The tests of protective coatings used in this technology were performed and strength $\left(R_{m}\right)$, permeability $(P)$, and gas evolution tendency of these coatings assessed. New solutions developed by the team of researchers were applied in testing coating strength, permeability, and the gas evolution tendency of expanded polystyrene. A good correlation between the results of coating properties and the obtained casting quality was found. Coatings, which were characterised by higher strengths and better permeability, allowed us to produce castings without surface or inner faults.
\end{abstract}

Key words: full-mould, coatings, strength, permeability, gas evolution tendency

\section{Streszczenie}

Dynamiczny rozwój produkcji odlewów w technologii „pełnej formy” wymaga szybkiej optymalizacji procesu technologicznego dla nowych kształtów odlewów. Wykonanie dobrych odlewów wymaga starannego doboru odpowiednich materiałów formierskich. W tym celu zaproponowano metodykę pomiarową dla wybranych, podstawowych parametrów materiałów formierskich. Określono wytrzymałość powłok ochronnych $R_{m^{\prime}}$ przepuszczalność powłok i gazotwórczość styropianu, jak również zaproponowano zmodyfikowaną wersję badań gazotwórczości materiałów dla modeli stosowanych w technologii „lost foam”. Określono kinetykę wydzielania gazów w funkcji

Jan Mocek Ph.D., Jerzy Zych Ph.D. D.Sc., Łukasz Krubnik M.Sc.: AGH University of Science and Technology, Faculty of Foundry Engineering, Department of Moulding Materials, Mould Technology and Cast Non-Ferrous Metals, Krakow, Poland; jzych@agh.edu.pl 
temperatury dla wybranej grupy spienionych polistyrenów. Stwierdzono dobrą korelację pomiędzy wytrzymałością i przepuszczalnością a uzyskiwaniem dobrych („zdrowych”) odlewów. Powłoki cechujące się wysoką wytrzymałością i przepuszczalnością pozwalają na produkcję odlewów bez wad. Potwierdzono to, wykonując serię próbnych odlewów ze stopu Al-Si.

Słowa kluczowe: pełna forma, powłoki, wytrzymałość, przepuszczalność, gazotwórczość

\section{Introduction}

The full-mould technology is based on placing a pattern made of expanded polystyrene covered by fire-resistant coatings in a moulding box, and then filling this pattern and gating system with loose sand. It is the first process in which moulding sand with no binding materials is used. This sand is then vibrated to ensure high compactness and density. Products formed due to pattern thermal destruction pass through the fire-resistant coating and sand and exit the mould [1].

Patterns of expanded polystyrene are used for making castings both from non-ferrous metal alloys and ferrous alloys. The obtained castings are of a dimensional accuracy similar to castings like permanent mould, shell, and investment castings. Casting surface quality corresponds with the surface quality of the polystyrene pattern, by its accurate representation. Today, there are more than one hundred foundry plants (mainly in America, England, France, Japan, Canada, Germany, Russia, Ukraine and Italy) that apply various versions of the full-mould technology for producing castings for machine, automotive, artistic, and other industries. This number is a significant increase from the late 1980s, when there were only a few dozen. The method of gasification pattern can be used for making precise castings of vehicle, machine, and devices parts of various materials (e.g., non-ferrous metal, ferrous, and magnesium alloys [2, 3]).

\section{Versions of the process}

The process of burned out patterns made of expanded polystyrene comes in trade names such as 'Full Mould,' 'Policast,', Replicast FM or CS', and 'Simplicast FM'. Several versions of the gasification pattern technology can be reduced to three basic variants:

1) full mould - intended for making castings of a mass of app. $1000 \mathrm{~kg}$ and larger, of cast iron and Al alloys, mainly for short-series or single-castings production.

2) lost foam - intended for making castings of a mass of app. $500 \mathrm{~kg}$ of cast iron and Al alloys, mainly for large-series production.

3) replicast - burned-out mould technology intended for making castings of cast steel of a mass of $250 \mathrm{~kg}$.

The polystyrene pattern in the full-mould 'FM' process is removed by means of gasification; this means by thermal destruction that occurs during the pouring of the mould with liquid metal. The thin-walled ceramic mould is not burned-out before the pouring process. It is covered by refractory material (once, twice, or three times) of a pre-determined thickness (usually 1-3 mm). Then, the whole set is placed in loose foundry sand. 
The mould prepared in such a way is additionally subjected to a vibration process in order to obtain better compacting of the sand used to fill the mould.

The polystyrene gasification is accompanied by carburizing the external casting part, which sometimes limits the application of the classical full-mould technology. Therefore, different versions of this process were developed.

The expanded polystyrene pattern, in the CS-type process (burned-out ceramic moulds), is first removed by burning-out in electric furnaces. Pattern sets are burned-out at temperatures of $800-1000^{\circ} \mathrm{C}$, which removes the pattern and simultaneously provides proper shell-coating strength. Instead of covering by one or two layers, several layers (additionally poured by refractory materials) are applied. Such a coating is of a 3-8 $\mathrm{mm}$ thickness. After being formed in loose sand, the metal is poured into an empty shell.

Simplicast FM technology. The polystyrene pattern covered by a refractory suspension (Stymorol) is applied in this method in order to harden the shell around the pattern. Low-density polystyrene (below $25 \mathrm{~kg} / \mathrm{m}^{3}$ ) is used for patterns, and their covering by suspension is done by means of the immersing method [1].

Replicast FM technology. This method is characterised by vacuous suction of gases from the mould bottom. This is aimed at mould life improvement. A grain coarseness of the dry sand applied equals $0.5-0.55 \mathrm{~mm}[2,4]$.

EPC technology. Patterns are immersed in the refractory cover, which is later dried. Then, the whole ceramic mould is placed in moulding sand with a binder. A mould prepared in such way is then poured with liquid metal.

It can be noticed that, when analysing the technical literature, highly-developed countries are currently going through a boom of the full-mould technology. It is expected that such growth will be maintained for the next 10 years; and according to this technology, $29 \%$ of total casting production of Al alloys, $15 \%$ of total cast iron castings, and $9 \%$ of total cast steel castings will be made.

An interest in this technology is also noticed in Poland. Gasification patterns are already applied for production of single castings in some foundry plants [5].

\section{Assessment of the strength and permeability of protective coating}

The covering of patterns by ceramic refractory coatings has a significant influence on casting quality. If the coating is deposited unevenly on the pattern, or if this coating has cracks, the casting will have faults (moulding sand burn-on, roughness), and sand erosion could be observed in the gating system. Even the mould could be distorted (dropped) [6]. Below are listed the requirements which should be met by the ceramic coating [6-8].

- It should prevent the liquid metal contact with the sand matrix.

- Proper strength (a coating should not crack during manipulations).

- Proper permeability. 
The pattern of expanded polystyrene is subjected to a high temperature influence during pouring with liquid metal. Gases formed during this process permeate by the refractory coating and limit the pouring rate. Therefore, the proper permeability of the formed gases is required from the protective coating. When this permeability is too small, a pressure in the gasified zone increases, which slows down the pouring rate as well as the pattern evaporation; in effect, the obtained casting is gasified. When the coating permeability is too high, gas pressure does not satisfactorily strengthen the protective coating and dry-sand matrix. This increases the probability of fault formation on the casting surface and even dropping of the mould $[3,5,6]$. Name-brand coatings of the determined parameters are applied for the protective coatings in the full-mould technology. These are more often than not water quartz coatings. After deposition on the pattern, they are dried in driers with a good air extractor.

\subsection{Assessment of the coating strength}

One of the main criteria of the suitability of protective coatings for full-mould technology is their immediate tensile strength, $R_{m}$. When the ceramic coating is deposited on the expanded polystyrene, several intermediate operations are performed - such as; pattern transporting to the drier, depositing successive coatings, placement of the coated pattern in the mould with dry sand, and mould pouring. During all of these operations, the coatings can be cracked or gaps can occur in them if not at sufficient strength. In effect, faulty casting is formed, with veins on its surface.

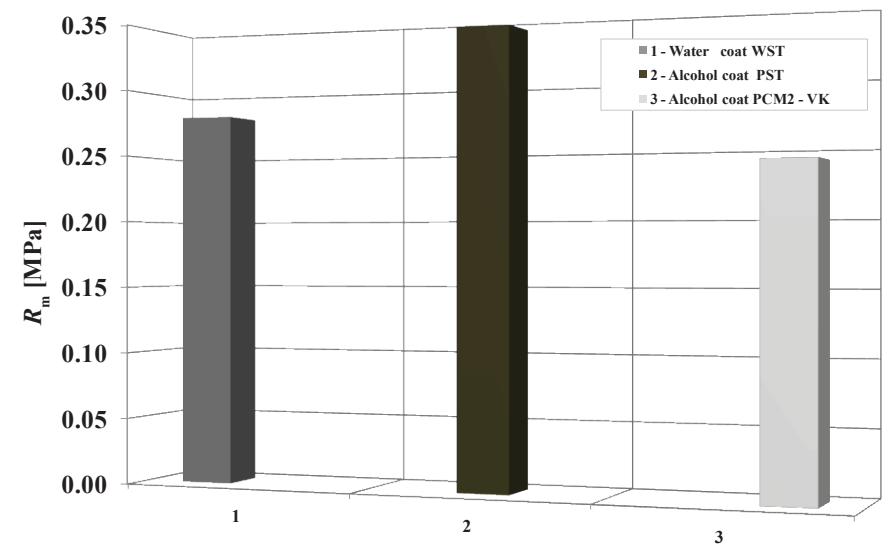

Fig. 1. Tensile strength of three coatings used in the full-mould technology

The lower the coating strength, the more layers that should be deposited on the polystyrene pattern to limit its cracking tendency. Unfortunately, such an operation leads to a decrease in mould permeability, which - in turn - leads to another group of castings faults (of a gaseous origin). 
Investigations of three grades of protective coatings recommended for the fullmould technology were performed. The previously-developed research methodology was used [9]. The results are presented in Figure 1. The assessed coatings are characterised by a similar strength $R_{m}$ value in the range: $0.25-0.35 \mathrm{MPa}$. The highest strength was obtained with the protective coating with an alcoholic diluent, the PST coating.

\subsection{Assessment of permeability}

The permeability of protective coatings applied in the full-mould technology constitutes one of the most important characteristics and technological properties. Unfortunately, a method that allows us to determine measuring standards has not been developed until now. Several attempts of such method development have been undertaken [10]. The successive proposal of testing protective coatings was developed recently in the Laboratory of Foundry Mould Technology of the Faculty of Foundry Engineering, AGH. The essence of this method was described in paper [10]. This method uses the standard device for measuring permeability of moulding and core sands. In order to create conditions of performing measurements and to increase structural strength, a sample of the multilayer coating is formed on a net (Fig. 2), in a similar fashion as in the former method $[1,8]$. This coating sample (of 2-3 layers) is glued to the bushing of the inner diameter: $\varnothing 50 \mathrm{~mm}$. After gluing, the standard permeability measurement is performed. On its basis, the actual coating permeability - in reference to its unit thickness - is determined by calculations.
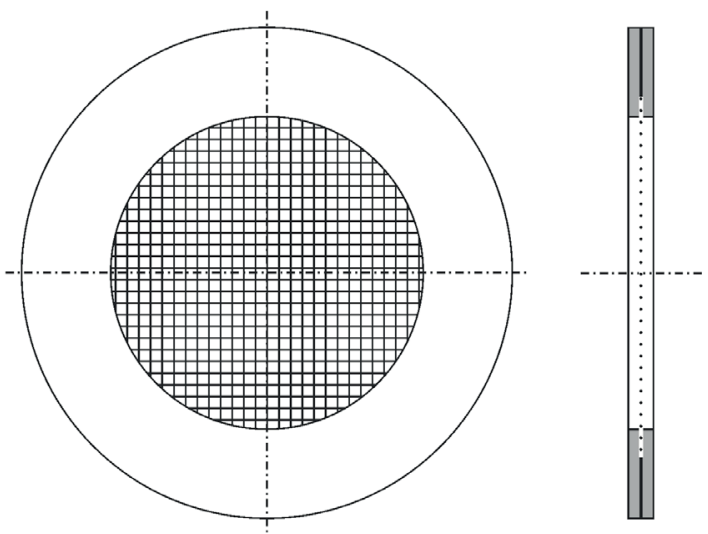

Fig. 2. Net prepared for forming the multilayer coating intended for permeability assessment

Among the tested coatings, two groups can be singled out: coatings with very good permeability (alcoholic coating: PROTECTA PTS) and coatings with much lower permeability (water: PROTECTA WST and alcoholic coating: PCM2VK) (Fig. 3). 


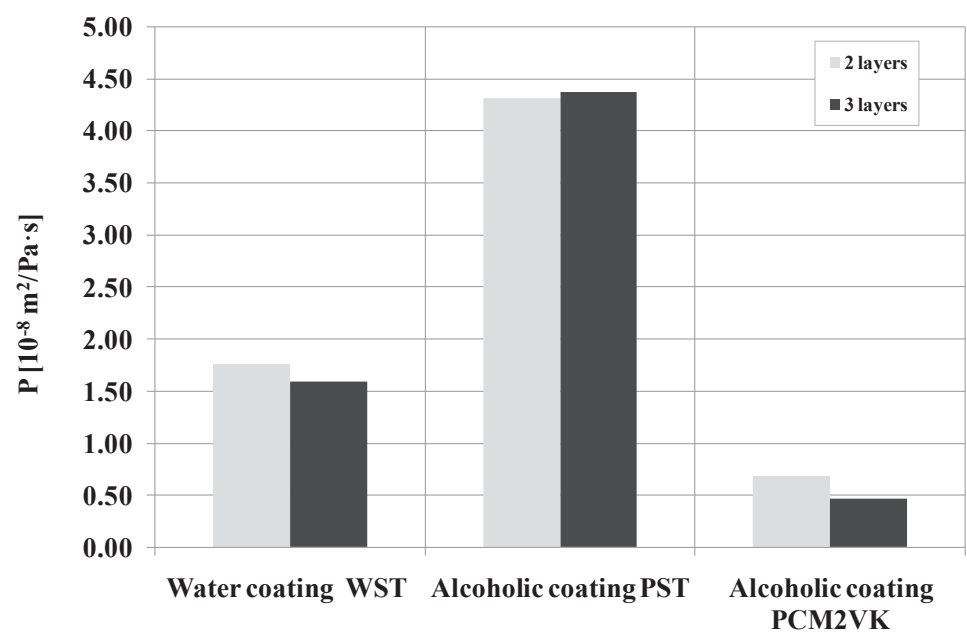

Fig. 3. Permeability of protective coatings intended for the full-mould technology

Too-low permeability of the coating in the full-mould technology causes a lack of fluidity in filling the mould with liquid metal. Gases emitted from the pattern material must be 'pushed out' from the mould cavity in a short time; otherwise, the metal flow and mould filling will be stopped. It is especially dangerous at making thin-walled castings, since incomplete fillings and cold shuts can then be formed.

The statement that the new method of testing the coating permeability is simple and very accurate (allowing us to put coatings in order even when the permeability differences are relatively small) is also a conclusion from our investigations.

\section{Kinetics of gases emissions the mould (expanded polystyrene pattern and protective coatings)}

\section{Emissions from the expanded polystyrene pattern}

The amount of gases formed during the expanded polystyrene gasification is important in the full-mould process. The total gas amount is important, but equally and even more important (deciding on technological success) is the kinetics of gas emissions. Thus, it is important how much of the gases are emitted in successive seconds or at the given temperatures. Gases formed due to the expanded polystyrene gasification permeate through the protective coating and sand to the outside of the mould. An incorrect process of gas permeation can be the reason for liquid metal gasification, changes of its chemical composition, and porosity formation [6].

The energy supplied by liquid metal should warrant the thermal decomposition of expanded polystyrene from a solid into a gaseous state - in an optimal time - to obtain castings of complex shapes and high quality. 
Technological parameters essential in the correct process realisation are listed below.

- Optimal chemical composition and pattern density.

- Mould permeability.

- Temperature of metal overheating.

- Type and parameters of a gating system.

- Metallostatic pressure [11].

Within our own investigations, the assessment of gas emission kinetics from three kinds of materials used in the full-mould technology was performed: white expanded polystyrene $\left(23.2 \mathrm{~kg} / \mathrm{m}^{3}\right)$, blue $\left(39.4 \mathrm{~kg} / \mathrm{m}^{3}\right)$, and extracted polystyrene of the brand name: Austrotherm XPS TOP $50 \mathrm{SF}\left(47.8 \mathrm{~kg} / \mathrm{m}^{3}\right)$, called 'pink' polystyrene from here out.

The modified version of the stand for the gas evolution tendency in the tubular furnace was applied for the assessment of the gas evolution kinetics. This stand modification was based on the introduction of temperature measurements of the heated polystyrene sample, which allowed us to collect data not only concerning the amount of gases but also the temperatures at which they were formed. The results of the gas evolution tendency of the tested expanded polystyrenes are presented in Figures 4-7.

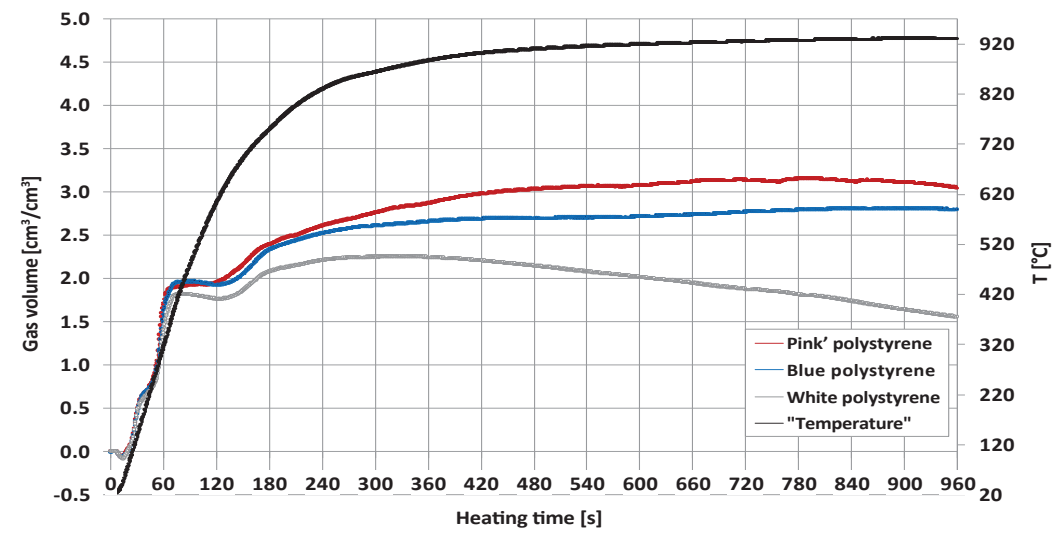

Fig. 4. Pathways of heating various polystyrene samples and gases emissions

The source material of the performed measurements constitutes the recorded notation of temperature changes of the heated polystyrene sample as well as the recorded notation of gas amounts evolved from the sample in successive seconds of heating. Such a notation is shown in Figure 4. The amount of evolved gases can be related either to $1 \mathrm{~g}$ or $1 \mathrm{~cm}^{3}$ of expanded polystyrene. More justified is the relation to the volume, since 
patterns are of determined dimensions and volumes. In such a perspective (in relation to the volume unit), the smallest gas amount is generated by white polystyrene, slightly larger by blue, and the largest by the 'pink' one. Differences reach more than $20 \%$. Each polystyrene sample is of another density.

Next to the amount, the important factor constitutes the gas evolution rate. The amount of gases evolved in successive seconds of heating is shown (for white polystyrene) in Figure 5. The remaining polystyrenes provide similar pathways of gas evolution. Three peaks of various sizes can be separated. The first two, more intensive, occur shortly after each other (after 30 and 60 s), and the third occurs much later (after app. 160 s).

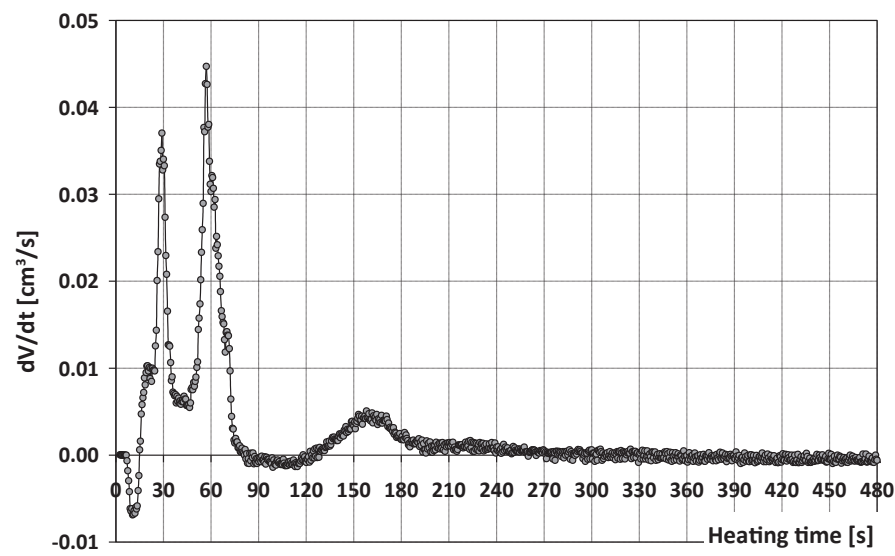

Fig. 5. Gas evolution rate from the intensely-heated white polystyrene

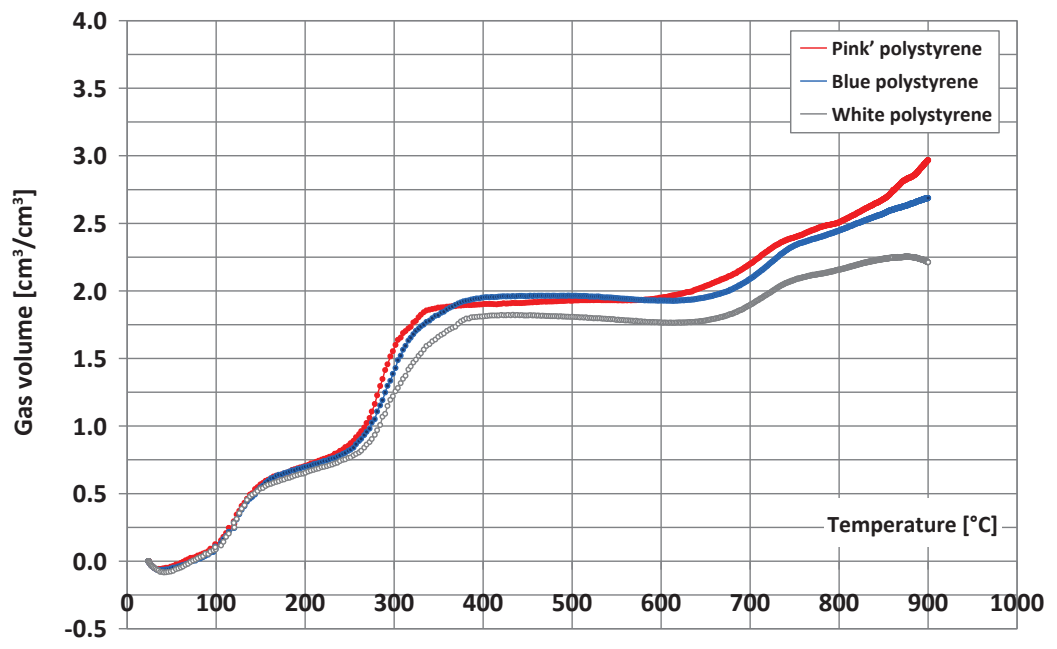

Fig. 6. Pathways of gas evolution during polystyrene sample heating. The temperature influence on the amount of gases evolved from $1 \mathrm{~cm} 3$ of expanded polystyrene 


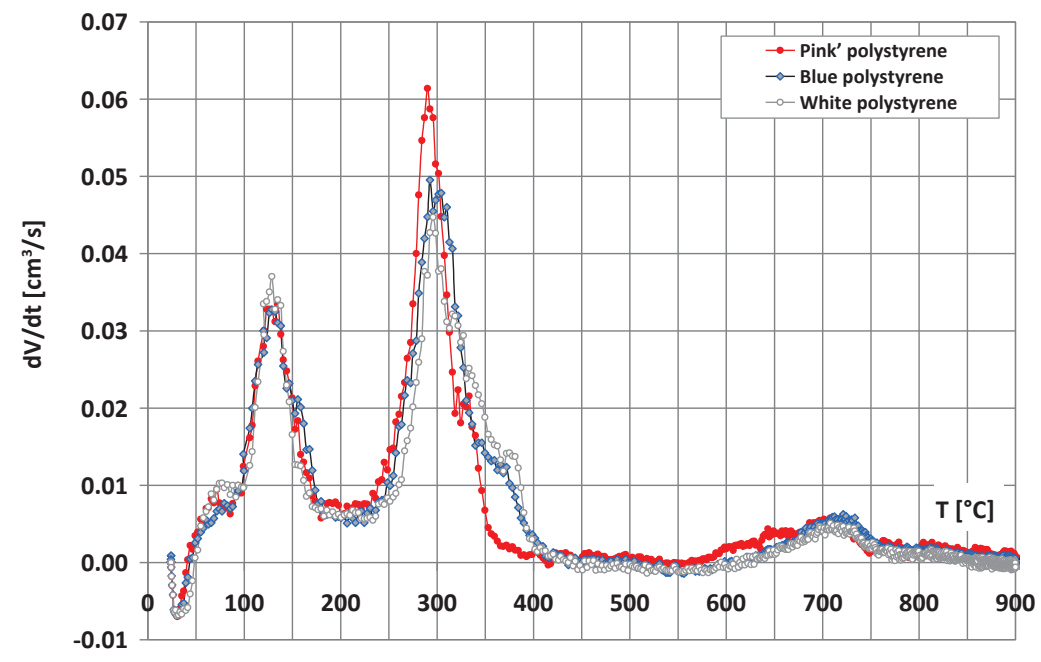

Fig. 7. Influence of the polystyrene heating temperature on gas evolution kinetics

The assignment of temperatures in which successive peaks occur is shown in Figures 6 and 7. Three temperature values at which a certain acceleration of the gas evolution can be noticed are shown in Figure 6 . It is seen very clearly in Figure 7, which was formed as derivative $\mathrm{dV} / \mathrm{dt}$ and to this derivative the temperature at which the gasifying process obtains the determined value, was assigned. These are temperatures: app. $130-140^{\circ} \mathrm{C}$ for the first peak; $\sim 300^{\circ} \mathrm{C}-$ for the second peak; and app. $700-750^{\circ} \mathrm{C}$ for the third (much smaller) peak. These are temperature ranges and values at which gas pressures in the mould rapidly increase, and this mould (coating) must be able to carry away these increasing amounts of gases. If the metallostatic pressure in the mould is insufficient, the so-called metal boiling (i.e., metal throwing out from the gating container) can occur in these moments. This unavoidably leads to faulty castings.

\section{Experimental stand}

The experimental stand for investigations of the full-mould technology was built in the Laboratory of Foundry Moulds Technology of the Faculty of Foundry Engineering, AGH. This is shown in Figure 8. This stand consists of a dry sand container to which an industrial vacuum cleaner is connected. Its aim is to excite the fluidised bed (it operates in the super-pressure system - blower) during immersion of the wax pattern in dry sand. The same vacuum cleaner - operating as a negative-pressure generator - allows a foil to press down the upper surface of dry sand in the container and to evacuate (from sand) gases formed during the pattern gasification, which occurs when 
the mould is poured with liquid metal. The vibrating system, seen at the container side, allows dry sand to compact more strongly after placing in it the polystyrene pattern covered by the coating. This stand is used for performing measurements and experiments as well as for didactic aims, such as the method presentation during laboratory classes.

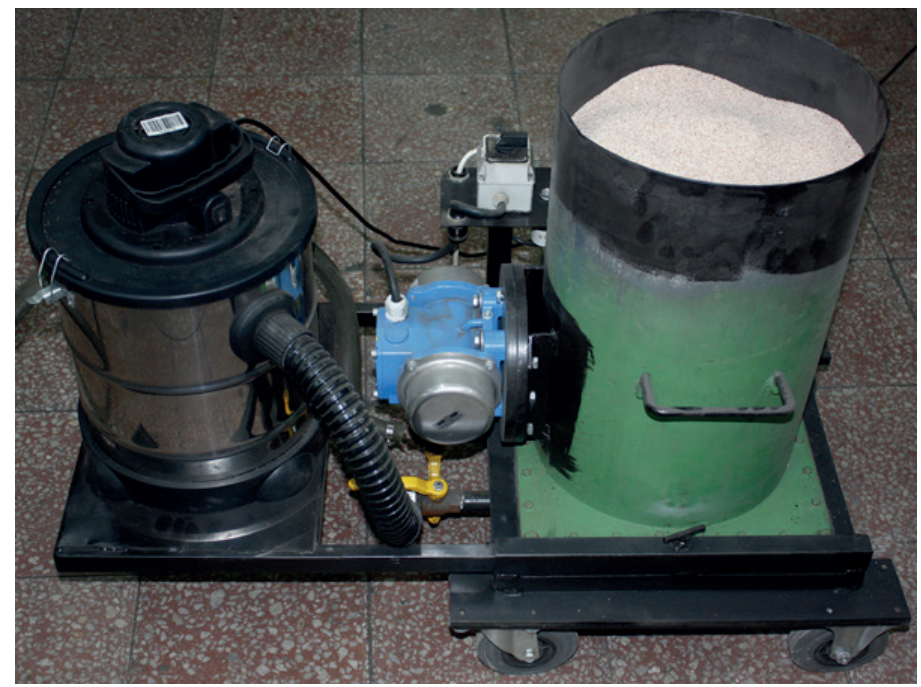

Fig. 8. Laboratory stand for the full-mould technology investigations

\section{Examples of castings made of al alloys}

\subsection{Art castings of al alloys}

A series of art castings were made within research concerning the full-mould technology. The point was to make thin-walled castings of Al alloys, which would be characterised not only by thin walls but also an increased roughness in as-cast condition. To achieve this aim, the technology of mechanically cutting out patterns by the heaterwire technique was selected. Patterns were made of a special type of polystyrene (polystyrene: Austrotherm XPS TOP 50 SF). Cutting was done at the stand of a numericallycontrolled plotter for cutting polystyrene. The polystyrene block from which individual patterns of art castings in the forms of statuettes were cut out - shown in Figure 9a. The achieved artistic effect of an increased coarseness - providing a specific artistic surface texture - is clearly seen in Figure 9b. The applied simple gating and flow-off systems allowed us to make several dozen statuettes of the Al alloy, silumin AK11, without rejected castings. 
a)

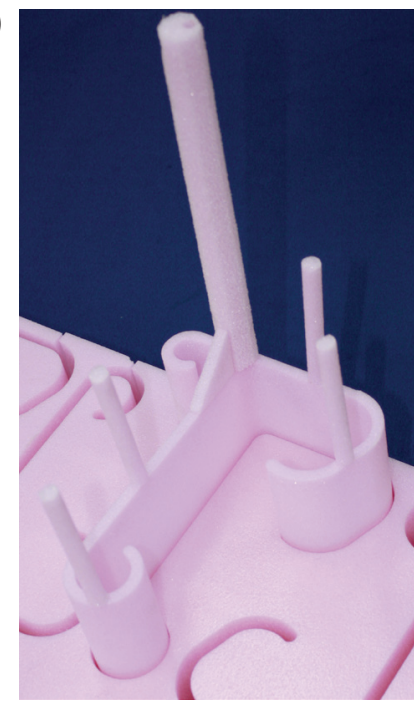

b)

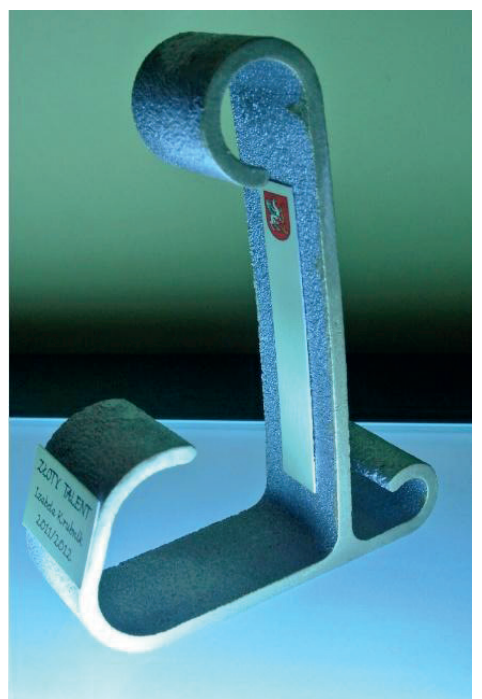

Fig. 9. View: a) pattern with the gating system; b) cast statuette [11]

\subsection{Functional quality of al alloys}

Several castings of functional quality were made in the same full-mould technology of the Al alloys. Technical possibilities of making thin-walled elements of expanded polystyrene patterns are created by modern techniques, including the cutting-out technique with applying plotters with a heater wire. Examples are shown in Figure 10.

a)

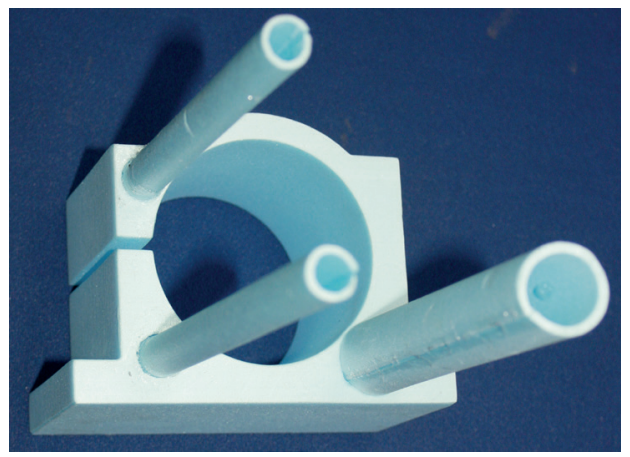

b)

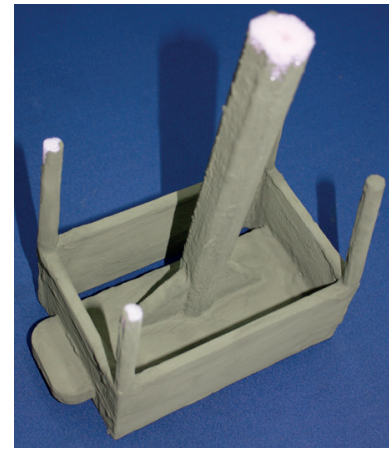

Fig. 10. Expanded polystyrene patterns made with the plotter application: a) pattern of blue polystyrene; b) pattern of white polystyrene after depositing the protective coating

Patterns reproducing the body of a small laboratory milling machine were made by the same technique. Castings made of Al-Si alloys are shown in Figures 11 and 12. At making prototypes of castings, technological problems almost always occur. The problem of retaining the proper shape of a relatively-large casting (in regards to laboratory conditions) is 
seen in Figures 11 and 12. The lack of loading (or weak loading) of the upper surface of the mould formed of dry sand can lead to lifting (displacement) of the upper surface from the expanded polystyrene pattern (detachment of the coating plane from the upper surface of the pattern). This also causes the upper wall movement and - in effect - changing the casting contour seen in the figures. An application of foil covering the upper surface of the mould and the generation of negative pressure is one of the methods limiting the effect described above. Another method is the normal, classic loading of the mould upper surface by pressure plates and standard pouring weights.

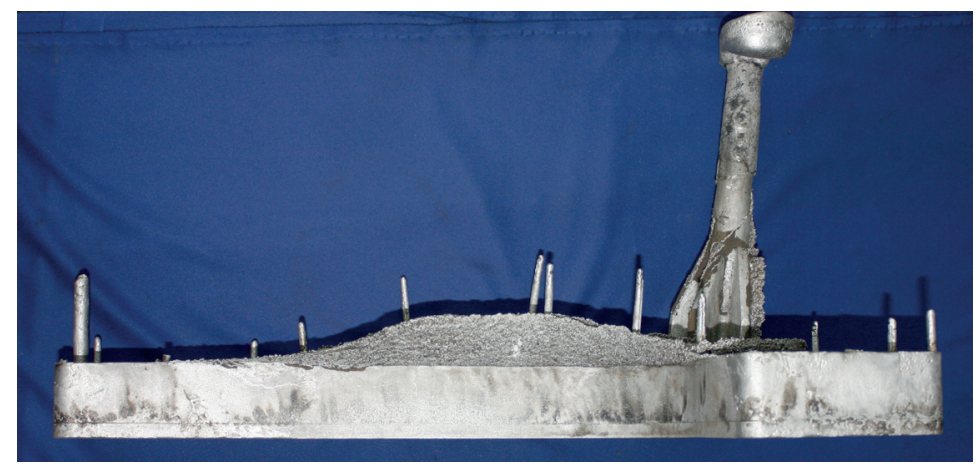

Fig. 11. Casting of the body with the upper surface fault, caused by an insufficient load of the upper surface of the sand mould

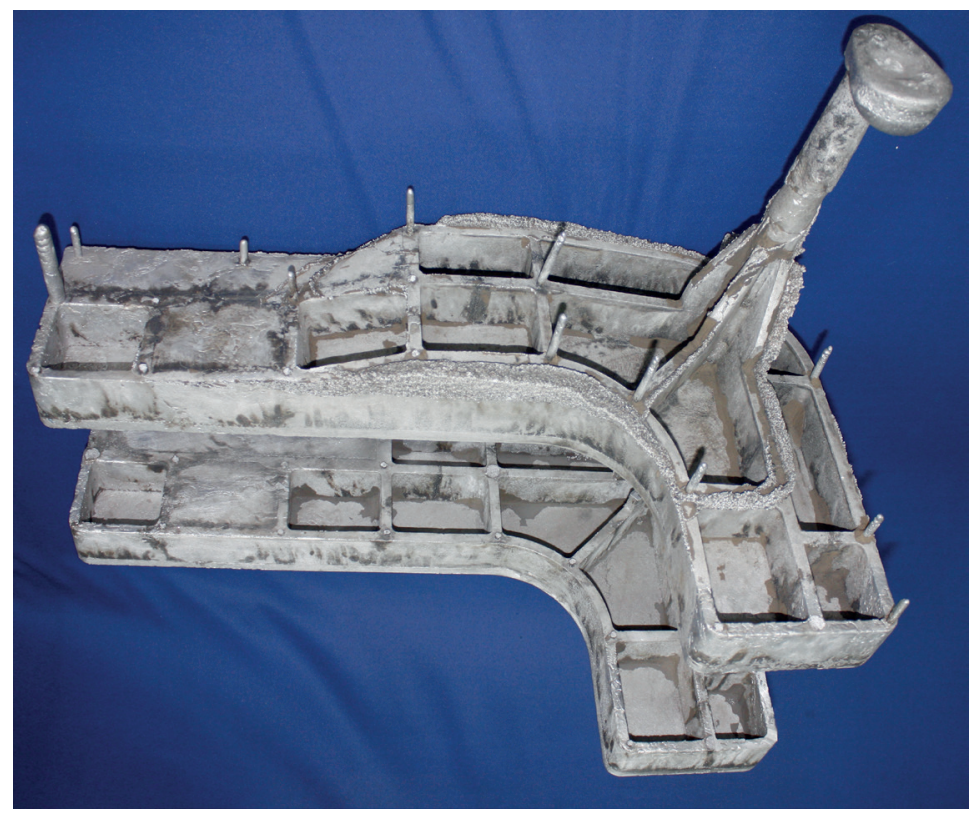

Fig. 12. Comparison of two castings of the body of the small milling machine: with a fault of the upper part (upper casting), properly made (lower casting) 


\section{Conclusions}

The full-mould technology has become more and more important in the world of casting production. Both small and large castings are produced by certain variants of this technology. More and more, complex shape castings of light metal (mainly Al alloys) are produced for the automotive industry. The main positive attribute of this technology is the possibility of imparting the 'arbitrary' shape on the final product (the casting). Apart from the full-mould technology, such a possibility provides only the lost foam technology, whose costs constitute a barrier at casting producing for the automotive industry.

On account of the existing and unavoidable gradual implementation of this technology, the authors of the hereby paper draw attention to the main problems of this technology, its possibilities, and possible methods of their solutions. This is the purpose of the research. New original research stands built in the Laboratory of Mould Technology allow the assessment of the quality of materials and raw materials applied in this technology, to shorten the time of achieving optimal solutions and to decrease the tests number at this technology implementation. This is the aim of investigating the coating permeability, its strength, the gas evolution tendency of expanded polystyrene, etc. Laboratory stands allow us to refine solutions in the scope of building gating systems, coatings, and pattern testing.

The development of pattern forming techniques with the application of plotters for cutting out polystyrene, accelerate preparative works, and the production being put into operation. This research does not concern the important problems of capturing and neutralising the chemical substances emitted when the mould is poured with liquid metals. The necessity of applying neutralisers of gases originated from the gasification of expanded polystyrene patterns is presently widely known and should be applied under production conditions.

\section{References}

[1] Jankowski W., Mocek J.: Technologia wytwarzania odlewów z zastosowaniem modeli ze spienionego polistyrenu. Instrukcja ćwiczenia laboratorium Wydziału Odlewnictwa AGH, Kraków, 2000

[2] Lewandowski J.L.: Tworzywa na formy odlewnicze. Akapit Press, Kraków, 1997

[3] Gnatush V.A., Syroporshniyev L.N., Chaykovskiy A.A.: Polucheniye otlivok po gazifitsiruyemym modelyam. Liteynoye Proizvodstvo, 2 (1996), 27

[4] Żółkiewicz Z.: Kinetyka cieplnego rozpadu modelu styropianowego oraz wpływ wydzielających się gazów na zawartość wodoru, azotu i tlenu w żeliwie szarym, w „procesie pełnej formy”, praca doktorska, AGH, Wydział Odlewnictwa, Kraków, 2001

[5] Tarantola B., Andre D.: Lost Foam Process-Reduction in the Generation of Carbon from Expanded Polystyrene. $64^{\text {th }}$ World Foundry Congress, Paris, 2000. Referat F33 
[6] Bates Ch., Littleton H., Stroom P., McMellon B.: Technological Developments and Worldwide Market Growth in Lost Foam Casting Production. 64 ${ }^{\text {th }}$ World Foundry Congress, Paris, 2000. Referat UA 72

[7] Hahn O., Wappelhorst M., Döpp R., Stork A., Sacharuk L., Rödel G., Simon W.: Czynniki wpływające na proces wypełnienia formy i jakość odlewu w technologii zgazowywanych modeli. Padeborner Symposium, Lost Foam 2000. Padeborn.

[8] Jankowski W.: Kryteria oceny ceramicznych powłok ogniotrwałych dla procesu pełnej formy. Materiały VIII Międzynarodowej Konferencji Naukowo-Techniczna. Zielona Góra, 1997, sekcja, III, 247-251

[9] Zych J.: Koncepcja badań wytrzymałości powłok ceramicznych stosowanych w technologii pełnej formy i technologii wytapianych modeli. XII Międzynarodowa Konferencja Naukowo-Techniczna Odlewnictwa Metali Nieżelaznych. Iwonicz, 4-6 czerwca 2009

[10] Zych J. Kolczyk J., Snopkiewicz T.: New investigation method of the permeability of ceramic moulds applied in the investment casting technology. Archives of Foundry Engineering. Polish Academy of Sciences. Commission of Foundry Engineering; 13, 2 (2013), 107-112

[11] Krubnik Ł.: Projekt i wykonanie statuetek artystycznych ze stopu AK okołoeutyktycznego w technologii pełnej formy - praca magisterska. AGH, Wydział Odlewnictwa, Kraków, 2013 